\title{
PENGARUH METODE TEMATIK GLOBAL BELAJAR TARJAMAH AL- QUR'AN TERHADAP PEMAHAMAN AL-QUR'AN SANTRI MADRASAH DINIYAH MIFTAHUL HUDA BETON MEGALE KEC. KEDUNGADEM KAB. BOJONEGORO
}

\author{
M. Masjkur \\ IAI Sunan Giri Bojonegoro \\ Email: $\underline{\text { masjkur@gmail.com }}$
}

\begin{abstract}
Abstrak
"Penelitian ini membahas tentang "Pengaruh Metode Tematik Global Terhadap Pemahaman Al-Qur'an Santri Madrasah Diniyah Miftahul Huda Dusun Beton Desa Megale Kecamatan Kedungadem Kabupaten Bojonegaro". Adapun masalah yang menjadi fokus penelitian adalah :(1) Bagaimana pelaksanaan metode Tematik Global belajar Tarjamah Al-Qur'an pada santri Madrasah Diniyah Miftahul Huda di Desa Megale Kecamatan Kedungadem Bojonegoro. (2) Bagaimana pemahaman Al-Qur'an santri Madrasah Diniyah Miftahul Huda di Desa Megale Kecamatan Kedungadem Bojonegoro. (3) Sejauh mana pengaruh metode tarjamah Al-Qur'an pada santri Madrasah Diniyah Miftahul Huda di Desa Megale Kecamatan Kedungadem Bojonegoro. Penelitian ini bertujuan : (1) Penulis ingin mengetahui bagaimana pelaksanaan metode Tematik Global belajar tarjamah Al-Qur'an pada santri Madrasah Diniyah Miftahul Huda di Dusun Beton, Desa Megale Kecamatan Kedungadem Bojonegoro. (2) Penulis ingin mengetahui bagaimana pemahaman Al-Qur'an santri Madrasah Diniyah Miftahul Huda di Desa Megale Kecamatan Kedungadem Bojonegoro. (3) Penulis ingin mengetahui sejauhmana pengaruh metode tarjamah Al-Qur'an pada santri Madrasah Diniyah Miftahul Huda di Desa Megale Kecamatan Kedungadem Bojonegoro. Dalam penelitian ini diperlukan data-data yang akurat dan valid. Adapun metode yang digunakan untuk memperoleh data adalah metode observasi langsung, metode dokumentasi dan metode angket. Penelitian dapat disimpulkan bahwa nilai koefisien korelasi sesudah test antara diberi metode tematik global terhadap pemahaman Al-Qur'an adalah koefisien korelasi pearson $>r$ tabel $(0,416>0,388)$, maka dapat diambil kesimpulan yaitu korelasinya signifikan."
\end{abstract}

Keyword: Metode Tematik, Santri, Diniyah, Tarjamah

\section{Pendahuluan}

Al Qur'an adalah kitab yang sudah di mudahkan oleh Allah untuk di pelajari dan di fahami oleh setiap level dan tingkatan umat manusia sebagaimana dinyatakan dalam QS Al Qamar:17 


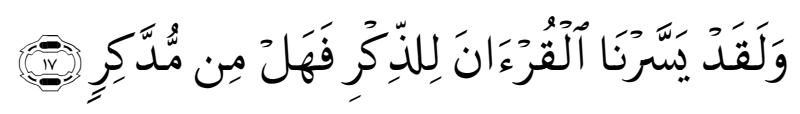

"Dan Sesungguhnya telah Kami mudahkan Al-Quran untuk pelajaran, Maka Adakah orang yang mengambil pelajaran?" 1

Al-Qur'an merupakan barometer atau ukuran setiap muslim dalam menjalankan pola perilaku kehidupan sehari-hari. Sebagai bentuk manefestasi manusia yang menjadikan AlQur'an sebagai sumber hukum yang pertama maka setiap kaum muslimin di berikan kesempatan untuk dekat dan akrap dengan Al-Qur'an untuk kemudian menjadi inspirasi sekaligus sebagai pedoman hidup dan petunjuk kehidupan sebagaimana di nyatakan didalam QS Al-Baqarah :2

Ilmu mempercepat kita sampai pada tujuan, agama menentukan arah yang dituju. Ilmu tidak jarang mengerahkan pikiran pemiliknya, sedangkan agama selalu menenangkan jiwa pemeluknya yang tulus. $^{2}$

Masalah kemerosotan moral dewasa ini menjadi santapan harian masyarakat kita. Meski dengan demikian tidak jelas factor apa yang menjadi penyebabnya. Kemerosotan moral adalah masalah pertama yang muncul pada diri manusia,"baik ideal maupun realita”. Secara ideal ketika manusia pertama kali diberi "roh" dalam kehidupannya maka padanya disertakan "Rasio" penimbang baik dan buruk. Secara realita dalam kehidupan masyarakat manusia,maka yang awal mula muncul dalam kesadarannya adalah pertanyaan. “apa yang dilakukan dalam hidup ini ?". pertanyaan ini ditunjukkan kepada kemampuan rohani pada diri manusia yang berbentuk kategori-kategori tertentu yang tidak timbul dari pengalaman manusia maupun pikiran manusia. Kemampuan ini bersifat intuitif dan apriori.

Mengapa di dunia sekarang tidak terwujud rohmatal lilalamin? karena Banyak yang belum memahami Al-Qur'an. Oleh karena itu maka di madrasah diniyah Miftahul Huda berusaha mengkaji Al-Qur'an untuk bisa memahaminya. Adapun metode yang dipakai adalah metode tematik global sebagai salah satu usaha yang diterapkan di Madrasah Diniyah Miftahul Huda kedungadem, dan berdasarkan pengalaman uji coba beberapa tahun terakhir ini banyak mengalami peningkatan peminat dalam kajian ini. Kajian tarjamah metode tematik global dapat

\footnotetext{
${ }^{1}$ Departemen Agama RI, Al-Qu'an Dan Terjemahnya ,CV. Diponegoro, Bandung, 2000 , hal.423

2 M.Quraish shihab._Wawasan Al-Qur'an, Mizan, Bandung, 2001,hal.376
} 


\section{Masjkur}

dilaksanakan secara klasikal atau kelompok dengan menggunakan formulasi khusus yaitu dengan program membuka Al-Qur'an mandiri tarjamah Al-Qur'an tematik global, cara cepat menuju khatam dan faham. Maka dalam mencoba menyusun ayat-ayat Al-Qur'an dengan cara kronologis dan kontruktif di alam tiga bentuk kajian yaitu: 1) Kajian tematik, menuju khatam dan faham. (2) Kajian tarjamah dengan shorof dan nahwu. (3) Kajian global dalam bentuk skematik dan ilustrasi.

Dari tiga bentuk inilah sebagai salah satu usaha untuk mewujudkan harapan pemahaman Al-Qur'an bagi anak-anak dan dewasa maupun tua. Dari uraian diatas penulis tertarik untuk mengkaji masalah tersebut.

\section{Pengertian Metode Tematik Global Belajar Tarjamah Al-Qur'an}

Menurut Muhammad Baqir Shadr metode tematik adalah berusaha mencari jawaban AlQur'an yang di mempunyai tujuan yang satu, yang bersama-sama. Membahas topik/judul tertentu dan menerbitkannya sesuai dengan masa turunya selaras dengan sebab-sebab turunnya, kemudian memperhatikan ayat-ayat tersebut, dengan penjelasan-penjelasan, keterangan-keterangan, dan hubungan-hubungannya.

Dengan ayat-ayat yang lain kemudian mengistimbatkan hukum- hukum. ${ }^{3}$ Di dalam bukunya Nashrudin baidan menyatakan bahwa tematik (maudhu'i) adalah membahas ayat-ayat Al-Qur'an sesuai dengan tema atau judul yang telah di tetapkan. ${ }^{4}$ Dari beberapa pengertian tematik di atas penulis dapat mengambil pengertian bahwa tematik adalah pembahasn ayat-ayat Al-Qur'an dalam tujuan tertentu sesuai dengan tema atau judul yang di tentukan berdasarkan asbabul nuzulnya.

Global dalam pengertian umum adalah menyeluruh yaitu pemgahasan Al-Qur'an secara menyeluruh, melalui suatu gambaran-gambaran atau skematik. Di dalam kamus ilmiah popular, global adalah seluruhnya, menyeluruh, garis besar, pada umumnya, secara utuh. Dalam arti bahwa pembahasan secara utuh tanpa terkurangi sedikitpun (didalam lingkup yang kecil tetapi mencakup seluruhnya.

\footnotetext{
${ }^{3}$ Muhammad Nur Ichwan, Memasuki dunia Al-Qur'an, Lubuk Raya ,Semarang, Th. 2001 hal.26

3 Ibid hal. 270

4 Muhammad Nur Ichwan, Loc Cit. hal.264
} 
Di dalam pengertian yang lain global (ijmali) adalah menafsirkan makna-makna ayatayat Al-Qur'an secara singkat dengan menjelaskan makna yang dimaksud pada setiap kalimat dengan bahasa yang ringkas sehingga mudah dipahami. ${ }^{5}$

Dari berbagai pengertian di atas dapat di simpulkan bahwa global adalah menjelaskan ayat-ayat Al-Qur'an secara ringkas tapi mencakup, dengan bahasa yang popular, mudah di mengerti dan enak di baca.

Setelah penulis uraikan beberapa pengertian metode, tematik dan global, maka penulis menjelaskan pengertian tentang belajar. Belajar merupakan salah satu usaha yang di sengaja dan mempunyai pengertian tertentu didalamnya juga mempunayai suatu tujuan. Tanpa terkecuali di dalam memberikan penjelasan mengenai belajar, maka harus dijelasakan pula pengertian dalam rangka memberikan arti yang mendekati kebenaran sebelum memberikan pengertian yang utuh pada kalimat di atas.

\section{Perwujudan Metode Tematik Global Belajar Tarjamah Al-Qur'an}

Metode yang dipakai adalah metode tematik global.” Maksudnya para peserta terlebih dahulu diajak untuk mengamati materi yang akan dipelajari ayat demi ayatnya secara global, kemudian ustadz ( pemandunya ) mengajak menganalisa tiap-tiap kata ( kalimatnya ), kemudian artinya, selanjutnya tarjamah tiap-tiap ayatnya (66 $^{60}$

Dalam hal perwujudan tarjamah Al-Qur'an ini dari beberapa ulama berpendirian bahwa dalam hal pembacaan Al-Qur'an dalam shalat dengan selain bahasa Arab, terbagi atas dua madzhab :

a. Boleh secara mutlak, atau disaat tidak sanggup mengucapkan dengan bahasa Arab.

b. Haram di dalam shalat dengan bacaan selain dengan menggunakan bahasa Arab.

Pendapat pertama adalah pendapat ulama madzhab Hanafi diriwayatkan dari Abu Hanifah bahwa ia berpendapat, boleh dan sah membacaa Al-Qur'an dalam shalat dengan bahasa Persia. Dan atas dasar ini sebsgian sahabat (muridnya) memperbolehkan pula membacanya dengan bahaasa Turki, India dan bahasa lainnya.

5Drs. Chalil umam, Ikhtisar Psikologi Pendidikan, Duta aksara Surabaya,Th.1998, hal 15.

6 TIM MKDK,Psikologi Pendidikan, Universitas pres IKIP Surabaya,Th.2000K, hal,111

15 Abdul Muhaimin As'ad dan H.M.Anas Adnan Lc, Kalimat Al-Qur'an , UD Indah Jaya Surabaya 2000, Hal,14 


\section{Masjkur}

Nampaknya mereka memandang dalam hal ini, Al-Qur'an adalah nama bagi nama-nama itu tidaklah berbeda-beda karene perbedaan lafadz dan bahasa.

Pendapat kedua adalah madzhab Syafi'i dan Hambali tidak memperbolehkan bacaan tarjamah Al-Qur'an dalam shalat, baik ia mampu membaca bahasa Arab ataupun tidak, sebab tarjamah Al-Qur'an bukanlah Al-Qur'an. Al-Qur'an adalah susunan perkataan mu'jizat'yaitu kalamullah yang menurut-Nya sendiri, berbahasa Arab. Dan dengan mentarjamahkannya itu bukan kalamullah. Dan terlihat di dalm firman-Nya:
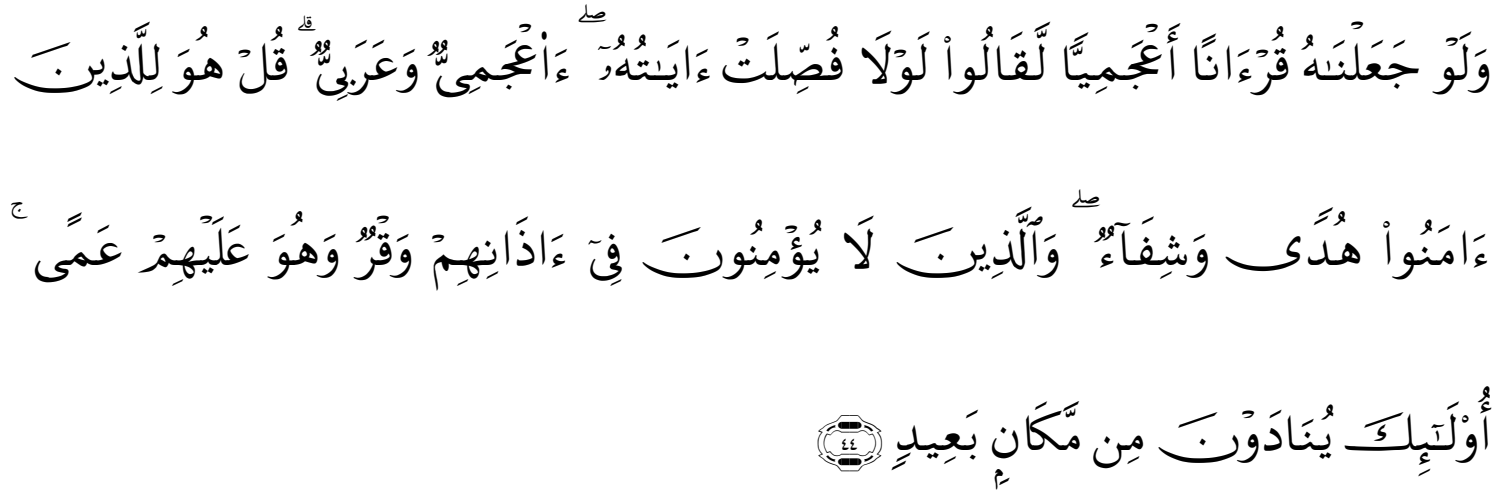

"Dan jikalau Kami jadikan Al-Qur'an itu suatu bacaan dalam bahasa selain Arab, tentulah mereka mengatakan :" Mengapa tidak jelaskan ayat-ayatnya ?". Apakah (patut Al-Qur'an ) dalam bahasa asing sedang (Rasul adalah orang ) Arab? Katakanlah : “AlQur'an itu adalah petunjuk dan penawar bagi orang -orang mukmin .’Dan orang-orang Yang tidak beriman pada telinga mereka ada sumbatan sedang Al-Qur'an itu suatu kegelapanka Yang tidak beriman pada telinga mereka ada sumbatan sedang Al-Qur'an itu suatu kegelapan Bagi mereka . Mereka itu adalah (seperti) yang dipanggil dari tempat yang jauh.” (QS. Al- Fussilat :44 $)^{7}$

\section{Usaha Dalam Metode Tematik Global Belajar Tarjamah Al-Qur'an}

Usaha dalam mentarjamahkan Al-Qur'an banyak dilakukan dalam berbagai bahasa, baik oleh orang-orang Barat maupun Timur.Tujuan utama dilakukan kegiatan ini adalah agar setiap muslim mampu memahami Al-Qur'an secara benar, khususnya bagi mereka yang tidak memahami bahasa arab yang merupakan bahasa Al-Qur'an.

${ }^{7}$ Departemen Agama RI, Al-Qur'an Dan Terjamahnya, Surya Cipta Aksara , Surabaya,1995, hal.779 
Maka semakin sulit jalan atau tujuan yang hendak dicapai, maka semakin nampaklah jelas kebenarannya . Terlihat pula semakin perlu dalam mengikuti aturan ataumetode untuk mencapai suatu tujuan yang diinginkan.

Cara-cara atau metode yang ditempuhnya antara lain adalah :

a. Kosa Kata

Dalam memahami tarjamah tematik diantaranya metode yang ditempuh adalah dengan memahami kosa kata. Salah satu tujuannya adalah untuk memahami bahasa Arab sebagai bahasa Al-Qur'an dengan benar. ${ }^{8}$ Di dalam penggunaan kosa kata kita dituntut untuk benar-benar bersabar agar tergesa-gesa dan bosan dalam memahami Al-Qur'an.

b. Menghafal ayat Al-Qur'an.

Selain metode kosa kata ada metode muroja'ah (menghafal berulang-ulang). Mengulang sesuatu akan semakin menancapkan hafalan dalam hati. Ada yang menyatakan bahwa "barang siapa yang mampu menghafal dengan cepat maka ia akan lupa dengan cepat pula, dan barang siapa yang mengkhatamkan dalam lima hari sekali maka dia tidak akan lupa, Maksudnya orang yang mengulang-ulang hafalan Al-Qur'an satu kali khatam dalam lima hari,maka umumnya hafalannya akan tertanam langgeng dalam hatinya. ${ }^{9}$

Dalam metode tematik dua cara ini ( kosa kata dan menghafal ayat Al-Qur'an ) setelah dilalui, maka santri akan menghadap ustadz/ustadzah ( setor hafalan ). Dengan cara sorogan (santri mmju satu per satu untuk menghafalkan didepan guru untuk muroja'ah). Setelah santri berusaha dengan beberapa metode pembelajaran dalamm metode tematik global maka santri diharapkan mampu:

a. Meyakini dan mengimani segi-segi akidah dan informasi yang ada dalam Al-Qur'an.

b. Mematuhi, artinya mematuhi perintah dan menjauhi larangannya serta mempraktekkannya didalam kehidupan sehari-hari terhadap diri sendiri maupun terhadap oerang-orang yang ada disekelilingnya.

Di Indonesia usaha menterjemahkan Al-Qur'an terhadap Al-Qur'an telah banyak dilakukan K.Bisri Musthafa Rembang dengan judul Al-Ibriz (1960), Al-Qur'an suci bahasa Jawi oleh

\footnotetext{
${ }^{8}$ Abdul Muhaimin,Tarjamah Kalimat Al-Qur'an,UD. Indah Jaya Ofset Surabaya .Hal.26

${ }^{9}$ Abdul Azis bin Muhammad As Sadhan,Cara Cepat Membaca Memahami dan Menghafal Al-qur'an,Pustaka Zeedny, Jakarta 2010, Hal.14
} 


\section{Masjkur}

Prof. KH.R. Muhammad Adnan (1969) dan Al-Huda oleh Drs.H.Bakri Syahid (1972) ${ }^{\mathbf{1 0}}$ Pemerintah Indonesia sendiri secara resmi juga telah melakukan usaha ini.

\section{Metodologi Penelitian}

Penelitian ini menggunakan metode kuantitatif sedangkan sampel yang diambil dari populasi seluruhnya yaitu kelas I Wustha ( 12 orang) dan kelas II Wustha ( 14 orang) jadi jumlah seluruhnya 26 orang ( $100 \%)$.

\section{Data Pemahaman Al-Qur'an Madrasah Diniyah Dusun Beton Desa Megale Kec. Kedungadem Kab. Bojonegoro}

Untuk mengetahui apakah ada pengaruh metode tematik global terhadap pemahaman $\mathrm{Al}$ Qur'an di Madrasah Diniyah Miftahul Huda ini, peneliti melakukan dengan berbagai cara antara lain : Peneliti mengobservasi selama 1 (satu) bulan sebelum memberikan metode tematik kepada sisa, sedangkan metode temamtik diberikan selama 1 (satu) bulan, kemudian peneliti mengobservasi kembali selama 1 (satu) bulan setelah metode tematik diberikan.

Sedangkan jenis data yang digunakan dalam penelitian ini adalah data kuantitatif, yaitu data yang dinyatakan dengan angka yang dapat dioperasikan dengan rumus-rumus statistik. Dalam penelitian ini data dikumpulkan dengan instrumen yang berbentuk angket, yaitu suatu daftar yang berisi serangkaian pertanyaan mengenai sesuatu masalah atau bidang yang diteliti. Sedangkan angket yang digunakan adalah angket tipe pilihan angket yang harus di jawab oleh responden dengan cara tinggal memilih salah satu jawaban yang sudah disediakan. Dengan jumlah alternatif jawaban 3 (tiga). Dalam penelitian ini mengadakan 1 angket metode tematik Global dan 1 angket pemahaman Al Qur'an dengan 3 (tiga) alternatif pilihan. Perhitungan skor interval 1-3 pada item-item sebagai berikut :

Skor 3 untuk jawaban A

Skor 2 untuk jawaban B

Skor 1 untuk jawaban $\mathrm{C}$

Seperti yang telah dikemukakan dalam metode penelitian, bahwa ini menggunakan metode angket (kuiseoner). Metode ini ini digunakan untuk mengetahui pengaruh metode tematik Global terhadap pemahaman Al Qur'an santri kelas 1 dan 2 wustho di Madrasah

\footnotetext{
${ }^{10}$ Muhammad Nur Ichwan, Op Cit,hal.242
} 
Diniyah Miftahaul Huda Dusun Beton Desa Megale Kecamatan Kedungadem Kabupaten Bojonegoro. Adapun jumlah angket yang disebar kepada responden berjumlah 26 angket sesuai jumlah responden.

Angket masalah untuk anak diberikan pada 1 minggu sebelum metode tematik dimulai, dan dilakukan pengamatan pada bulan sebelum metode tematik diberikan, dengan tujuan untuk mengetahui respon pemahaman Al Qur'an santri. Angket maslah untuk anak disebarkan 3 hari setelah metode tematik selesai. 1 bulan setelah metode tematik diberikan, dilakukan pengamatan kembali untuk mengetahui perkembangan pemahaman Al Qur'an santri.

Pada pengamatan awal 1 bulan sebelum dilakukan metode tematik Global, ada 12 santri yang dapat menjelaskan pemahaman ayat Al Qur'an, pada pengamatan yang kedua yang dilakukan setelah mempelajari metode tematik Global, ada sekitar 20 yang setiap hari dapat hafal dan memahami ayat-ayat Al Qur'an . karena selain itu juga ada materi tambahan kisahkisah Nabi dan materi keislaman.

\section{Analisa Kualitatif}

Dari hasil pengumpulan dan pengolahan data dari dua variabel yang digunakan dalam penelitian ini yaitu metode tarjamah tematik Global dan pemahaman Al Qur'an pada santri Madrasah Diniyah Miftahul Huda. Sebelum santri diberi pelajaran metode tarjamah tematik global disimpulkan tidak terdapat hubungan yang signifikan antara metode tematik Global dan pemahaman Al Qur'an pada santri Madrasah Diniyah Miftahul Huda.

Setelah para santri diberi metode tematik Global disimpulkan terdapat hubungan yang signifikan antara metode tematik Global dan pemahaman Al Qur'an santri kelas 1 dan 2 di Madrasah Diniyah Miftahul Huda Dusun Beton Desa Megale Kecamatam Kedungadem Kabupaten Bojonegoro. Koefisien korelasi yang didapatkan adalah positif sehingga hubungan yang terjadi adalah searah. Dengan demikian ada hubungan positif antara metode tematik Global dengan pemahaman Al Qur'an santri kelas 1 dan 2 di Madrasah Diniyah Miftahul Huda Dusun Beton Desa Megale Kecamatam Kedungadem Kabupaten Bojonegoro. Hal ini berarti apabila metode tematik global lebih ditingkatkan baik dalam bentuk kuantitas maupun kualitas akan diikuti peningkatan pada pemahaman Al Qur'an santri, dan sebaliknya setiap terjadi penurunan pada metode tematik global akan diikuti penuruanan pada pemahaman Al Qur'an pada santri. 


\section{Masjkur}

Pada santri Madrasah Diniyah Miftahul Huda dapat dilihat pada awal sebelum diberi metode tarjamah tematik Global intensitas santri yang memahami Al Qur'an hanya 12 santri dan yang tidak aktif sebanyak 4 santri, akan tetapi setelah pemberian metode tarjamah tematik Global ada 20 santri yang aktif dan yang tidak aktif sudah tidak ada. Dapat disimpulkan disini bahwa pemberian metode tarjamah tematik Global pada santri Madrasah Diniyah Miftahul Huda ternyata membawa dampak baik dalam merubah siswa dalam memahami ayat Al Qur'an. Hasil penelitian memperkuat pendapat para ahli mengenai pengaruh metode tarjamah tematik Global terhadap pemahaman Al Qur'an.

\section{Analisa Kuantitatif}

Analisa deskriptif sebelum tes dilakukan dengan mencapai prosentase alternatif jawaban pada variabel metode tematik dan pemahaman Al Qur'an. Berikut ini adalah tabulasi jawaban responden pada variabel metode tematik Global.

Hasil prosentase dari responden diketahui bahwa jawaban dari alternatif A sebanyak 10,39\%, jawaban alternatif B sebanyak 42,31\% dan jawaban alternatif C sebanyak 47,31\%. Jadi dapat disimpulkan bahwa pada variabel metode tematik global jawaban yang paling dominan adalah C (47,31\%). Untuk variabel pemahman Al Qur'an tabulasi jawaban responden adalah :

Hasil prosentase dari responden diketahui bahwa jawaban dari alternatif $\mathrm{C}$ sebanyak $54,62 \%$, jawaban alternatif B sebanyak 43,85\% dan jawaban alternatif A sebanyak 1,54\%. Jadi dapat disimpulkan bahwa pada variabel metode tematik global jawaban yang paling dominan adalah $\mathrm{C}(54,62 \%)$.

Sementara itu untuk analisa deskriptif sesudah test juga telah dilakukan dengan mencari prosentase alternatif jawaban variabel metode tematik Global dan pemahaman Al Qur'an. Berikut ini adalah tabulasi jawaban responden pada variabel metode tematik Global :

Hasil prosentase dari responden diketahui bahwa jawaban dari alternatif $\mathrm{C}$ sebanyak 15,77\%, jawaban alternatif B sebanyak 34,23\% dan jawaban alternatif A sebanyak 50\%. Jadi dapat disimpulkan bahwa pada variabel metode tematik global jawaban yang paling dominan adalah A (50\%). Untuk variabel pemahman Al Qur'an tabulasi jawaban responden adalah :

Hasil prosentase dari responden diketahui bahwa jawaban dari alternatif $\mathrm{C}$ sebanyak 11,92\%, jawaban alternatif B sebanyak 55,38\% dan jawaban alternatif A sebanyak 32,69\%. Jadi 
dapat disimpulkan bahwa pada variabel metode tematik global jawaban yang paling dominan adalah B $(55,38 \%)$.

Teknik analisis data yang digunakan untuk mengetahui hubungan antara metode tematik global dan pemahaman Al Qur'an adalah analisis koefisien korelasi producj Moment Pearson. Apabila nilai dari koefisien korelasi pearson > r tabel, maka dapat disimpulkan bahwa terdapat hubungan yang signifikan (nyata) antara variable bebas dan variable terikat. Dan sebaliknya juka nilai koefisien korelasi pearson < r tabel, maka disimpulkan tidak terdapat hubungan yang signifikan antara variable bebas dan variable terikat.

Hasil analisis korelasi sebelum test dan seseudah test antara metode tematik Global dan pemahaman Al Qur'an dapat dilihat pada table 11 dan table 12 sebagai beriku dengan rumus :

$$
r_{x y}=\frac{N \sum X Y-\left(\sum X\right)\left(\sum Y\right)}{\sqrt{\left\{\left\{N \sum X^{2}-\left(\sum X\right)^{2}\right\}-\left\{N \sum Y^{2}-\left(\sum Y\right)^{2}\right\}\right\}}}
$$

Nilai koefisien korelasi sebelum test antara tidak diberi metode tematik Global terhadap pemahaman Al Qur'an sebesar 0,334, maka dapat diputuskan korelasinya tidak signifikan. Artinya, tidak ada hubungan antara metode tematik Global dan pemahaman Al Qur'an santri kelas I dan Kelas II Madrasah Diniyah Miftahul Huda Dusun Beton Desa Megale Kecamatan Kedungadem Kabupaten Bojonegoro.

Nilai koefisien korelasi sesudah test antara tidak diberi metode tematik Global terhadap pemahaman Al Qur'an sebesar 0,416, karena koefisien korelasi pearson > r table $(0,416>$ 0,416) maka dapat diputuskan korelasinya signifikan. Artinya, terdapat hubungan antara metode tematik Global dan pemahaman Al Qur'an santri kelas I dan Kelas II Madrasah Diniyah Miftahul Huda Dusun Beton Desa Megale Kecamatan Kedungadem Kabupaten Bojonegoro.

\section{Kesimpulan}

Metode tematik global belum dilaksanakan di Madrasah Diniyah Miftahul Huda Dusun Beton Desa Megale Kecamatan Kedungadem Kabupaten Bojonegoro dan baru diterapkan selama satu bulan pada saat penelitian dilakukan. Setelah diadakan uji coba metode tematik global selama tiga bulan ada perubahanPemahaman terhadap yaitu 1) Santri mampu menghafal ayat per kosa kata. 2).Santri mampu mentarjamahkan al-Qur'an . 3) Santri mampu memahami Al-Qur'an, berarti ada pengaruh metode tematik global 


\section{Masjkur}

dengan dengan pemahaman Al-Qur'an santri Madrasah Diniyah Miftahul Huda Dusun Beton Desa Megale Kecamatan Kedungadem Kabupaten Bojonegoro.

Setelah pemberian metode tematik global terdapat hubungan antara metode tematik global dengan pemahaman Al-Qur'an santri Madrasah Diniyah Miftahul Huda Dusun Beton Desa Megale Kecamatan Kedungadem Kabupaten Bojonegoro. Sebagaimana analisis

nilai koefisien korelasi sesudah tes antara diberi metode tematik global terhadap pemahaman Al-Qur'an adalah 0,416. Karena koefisien korelasi pearson >r table ( 0,614 > 0,388), maka dapat diputuskan korelasinya signifikan.

\section{Daftar Pustaka}

Arikunto, S., Prosedur Penelitian, Rineka Cipta, Jakarta 2006.

As'ad, Abdul Muhaimin dan Adnan ,M. Anas, H, Lc, Kalimat Al-Qur'an, UD Indah Jaya, Surabaya 2000.

Ash- Shiddieqy, M. Hasby, Ilmu-ilmu Al-Qur'an, CV. Bulan Bintang, Bandung, 2000.

Azis, Abdul bin Muhammad As sadhan, Cara cepat membaca,memahami,dan menghafal AlQur'an, Pustaka Zeedny, Jakarta 2010.

Baidan Nashruddin, Dr. Metodologi Penafsiran Al-Qur'an,Pustaka Pelajar,Yogyakarta, 2000.

Baidan Nashruddin, Dr. Metodologi Penafsiran Al-Qur'an,Pustaka Pelajar,Yogyakarta, Th. 2000.

C., Narbuko dan A. Achmadi, Metodologi Peneiitian,Bumi Aksara, jawa Tengah 1997.

Departemen Agama RI,Al-Qur'an Dan Tarjamah,CV.Diponegoro, Bandung Th. 2000.

Departemen Agama RI, Al-Qur'an Dan Tarjamahnya,Surya Cipta Aksara, Surabaya, 1993

Depag. RI AL-ALIYY, Al-Qur'an Dan Tarjamahnya, Diponegoro, Bandung, 2000.

Departemen P \& K, Kamus Bahasa Indonesia,Balai Pustaka, Jakarta Th.1990.

Hadi, Sutrisno, MA., Metodologi Research, Fakultas Psikologi UGM, Yogyakarta 1987

Manna Khalil Al-Qur'an, Studi ilmu-ilmu Al-Qur'an,Litera Antar Nusa,Bogor, Th.2001.

Manna Khalil Al-Qattan, Studi ilmu-ilmu Al-Qur'an, Litera Antar Nusa,Bogor, Th.2001. 
Muhaimin, Abdul, Tarjamah Kalimat Al-Qur'an ,UD. Indah Jaya Ofset Surabaya.

Nor Ikcwan, Muhammad, Memasuki Dunia Al-Qur'an, Lubuk Raya, Semarang, Th. 2001.

Muhammad, Syekh bin Muhammad Abu Syahbah, Prof., Studi Al-qur'an Al-Karim, Pustaka Setia, Bandung, 2002.

Qordowi Yusuf, DR., Berinteraksi Dengan Al-Qur'an, Gema Insani Press, Jakarta Th. 2000

Ramak, Tri, Drs.Kamus Lengkap Bahasa Indonesia,Mitra Pelajar, Surabaya 2001.

Shaleh, KH. ,Asbabun Nuzul Latar Belakang Histories,CV. Diponegoro Bandung 2009.

Shihab, M. Quraish, Wawasan Al-Qur'an, Mizan ,Bandung,November, 2001.

Shihab, M. Quraish, Wawasan Al-Qur'an, Mizan ,Bandung, 2001.

Sugiono, Metode Penelitian Kuantitatif dan Kualitatif R dan D,Alfabeta, Bandung, 2007.

TIM MKDK, Psikologi Pendidikan,Universitas press, Surabaya,Th.2000.

Umam, Chalil, Drs.Ikhtisar Psikologi Pendidikan,Duta Aksara Surabaya, Th.2000.

Yulius, Drs. Kamus Baru Bahasa Indonesia, Usaha Nasional Surabaya, 2000.

Yahya, Abu Zakariya bin Syarofunnawawi, Riyadlusshalihin, Raja Murah, Pekaongan. 